\author{
Katarzyna Pocheć \\ Ministerstwo Gospodarki i Pracy
}

\title{
SOLVIT - skuteczna pomoc dla przedsiębiorcy w Unii Europejskiej
}

Rynek Wewnętrzny jest tym elementem Unii Europejskiej, który w najbardziej bezpośredni i widoczny sposób wpływa na życie każdego obywatela czy przedsiębiorcy. Jego istotą jest utworzenie obszaru, w ramach którego obywatele Unii Europejskiej mogą swobodnie realizować swoje projekty - osobiste i zawodowe, i w którym przedsiębiorcy swobodnie prowadzą swoją działalność. Rynek Wewnętrzny gwarantuje przedsiębiorstwom na przykład możliwość sprzedaży produktów na całym terytorium Unii czy zakładania filii na rynkach lokalnych. Zasady Rynku Wewnętrznego mają za zadanie umożliwić realizację takich zamierzeń i dążyć do wyeliminowania wszelkich przeszkód stanowiących hamulce dla tego typu inicjatyw.

Niemniej jednak, niezależnie od tego, z jaką dbałością konstruowane są ramy prawne Rynku Wewnętrznego, nie da się uniknąć błędów, nieporozumień i sporów, choćby tylko ze względu na ogromną ilość transakcji międzynarodowych i przepływów transgranicznych. Sprawne i skuteczne rozwiązywanie problemów praktycznych ma decydujące znaczenie dla wiarygodności Rynku Wewnętrznego w oczach obywateli i podmiotów gospodarczych, w tym głównie małych i średnich przedsiębiorstw. Jest to szczególnie istotne w odniesieniu do nowych Państw Członkowskich, w których taka wiarygodność jest dopiero budowana.

Ponieważ zadaniem Komisji jest zagwarantowanie pełnego poszanowania prawa wspólnotowego przez Państwa Członkowskie, poszukuje ona coraz to nowych sposobów, aby realizować to zadanie. $\mathrm{W}$ tym duchu, oraz $\mathrm{w}$ celu promowania alternatywnego rozstrzygania sporów, Komisja wystąpiła z inicjatywą utworzenia systemu opartego na współpracy między Państwami Członkowskimi. Zadaniem tego systemu ma być udzielanie pomocy wszystkim tym, którzy decydując się na skorzystanie z praw, jakie oferuje im Rynek Wewnętrzny, napotykają na przeszkody wynikające z błędów popełnianych przez organy administracji innego Państwa Członkowskiego. W ten sposób utworzona została sieć SOLVIT.

SOLVIT jest systemem nieformalnego rozwiązywania problemów, na jakie napotykają przedsiębiorcy i obywatele uczestniczący w funkcjonowaniu Rynku Wewnętrznego, a wynikających z nieprawidłowego stosowania prawa europejskiego przez organy administracji publicznej w Państwach Członkowskich. System działa w oparciu o współpracę Centrów Koordynacyjnych utworzonych w strukturach administracji każdego z Państw Członkowskich. Centra te, przy aktywnym współudziale ekspertów z administracji krajowej, zmierzają do wypracowania satysfakcjonującego dla wnioskodawcy rozwiązania.

Polska włączyła się w działanie SOLVIT z dniem 1 maja 2004 r. ${ }^{1}$ Od tego momentu polscy obywatele i przedsiębiorcy, których prawa zostały zanegowane lub ograniczone w wyniku niewłaściwego zastosowania $\mathrm{w}$ ich sprawie przepisów wspólnotowych przez ad-

\footnotetext{
${ }^{1}$ Polskie Centrum Koordynacyjne SOLVIT mieści się w: Ministerstwie Gospodarki i Pracy, Departament Stosunków Europejskich i Wielostronnych; Plac Trzech Krzyży 3/5,00-507 Warszawa tel.: +22 69353 60; Fax: +22 69340 80; Email: solvit@mg. gov.pl; www.solvit.gov.pl
} 
ministrację innego Państwa Członkowskiego, mogą zwrócić się do polskiego Centrum Koordynacyjnego z prośbą o pomoc. Sprawy zgłaszane do systemu SOLVIT w zakresie problemów w prowadzeniu działalności przez przedsiębiorców dotyczą bardzo różnorodnych kwestii: nieuzasadnionych kontroli granicznych towarów transportowanych między Państwami Członkowskimi; problemów wynikających z faktu, że władze na szczeblu krajowym nie dopuszczają do sprzedaży specjalistycznego sprzętu, mimo że produkt ten został dopuszczony do sprzedaży w Państwie Członkowskim pochodzenia; zwrotu podatku VAT uiszczonego w innym kraju UE niż kraj, w którym przedsiębiorca jest płatnikiem VAT.

Oto kilka przykładów spraw, w których dzięki interwencji SOLVIT znaleziono satysfakcjonujące rozwiązanie dla problemów, na jakie napotykają polscy przedsiębiorcy podbijający unijne rynki.

W ramach realizacji umowy kupna-sprzedaży polski przedsiębiorca przewoził z Polski do Estonii wyprodukowany przez siebie towar zakupiony przez klienta z Estonii. Jego samochody przewożące towar zostały zatrzymane na granicy, gdzie Estońska Straż Graniczna zażądała przedstawienia lincencji wspólnotowej na wykonywanie przewozu rzeczy. Zgodnie z rozporządzeniem Rady $\mathrm{UE}^{2}$ wymagania posiadania licencji wspólnotowej dotyczą wyłącznie przedsiębiorców trudniących się międzynarodowym zarobkowym przewozem drogowym. Natomiast w zaistniałej sytuacji przedsiębiorca wykonywał przewóz, który zgodnie $\mathrm{z}$ art. 4 załącznika II do rozporządzenia jest zwolniony z wszelkich zezwoleń wspólnotowych. Nie było zasadne żądanie licencji wspólnotowej na przewóz, zostały bowiem spełnione wszystkie kryteria zastosowania zwolnienia przewidziane w tym artykule:

- przewożone rzeczy zostały wyprodukowane przez przedsiębiorcę, a następnie sprzedane klientowi w Estonii (art. 4 pkt a),

- $\quad$ rzeczy przewożone były na własne potrzeby - celem dostarczenia ich klientowi (art. 4 pkt b),

- zatrzymane samochody prowadzone były przez pracowników przedsiębiorstwa (art. 4 pkt c),

- samochody stanowiły własność przedsiębiorstwa (art. 4 pkt d),

- przewóz stanowił tylko działalność pomocniczą w stosunku do działalności głównej przedsiębiorstwa (art. 4 pkt e).

Po kilku dniach postoju na granicy i długich perswazjach samochody zostały przepuszczone przez granicę, ale tylko warunkowo. Mimo iż polskie przedsiębiorstwo uzyskało wiele zamówień od klienta w Estonii, zmuszone było wstrzymać realizację umów, obawiając się, że samochody zostaną znów bezpodstawnie zatrzymane na granicy. W efekcie przedsiębiorca ponosił ryzyko utraty klienta.

W wyniku interwencji Centrum SOLVIT estońskie służby graniczne zostały poinformowane o istnieniu opisanego wyżej wyjątku przewidzianego przez rozporządzenie 881/92 oraz przekonane, że należące do polskiego przedsiębiorcy samochody miały prawo wjechać na terytorium Estonii. Estońskie służby graniczne przyznały rację polskiemu przedsiębiorcy; podkreślono jednak, że oficerowie służb granicznych mają obowiązek kontrolować autentyczność dokumentów. W konsultacji pomiędzy centrami SOLVIT oraz władzami estońskimi ustalono, że również w interesie własnym przedsiębiorcy jest, aby kierowcy pojazdów transportujących towary posiadali dokumenty wyjaśniające, na jakiej podstawie wjeżdżają na terytorium innego Państwa Członkowskiego. Ponadto, mimo iż nie istnieja podstawy prawne dla obowiązku wystawiania dokumentów w którymś konkretnym języku oficjalnym UE, dla usprawnienia standardowo przeprowadzanych kontroli pożądanym byłoby, aby dokumenty przedstawiane służbom granicznym przez kierowcę wystawiane były w języku znanym obu stronom.

Rezultatem przedstawionej powyżej sprawy było więc nie tylko rozwiązanie konkretnie zaistniałego problemu, ale również wypracowanie pewnej praktyki, która może zaowo-

${ }^{2}$ Rozporządzenie Rady EWG z dnia 26 marca 1992 nr 881/92, Dz. U. L 095 09/04/1992. 
cować na przyszłość usprawnieniem przepływu towarów między Państwami Członkowskimi, a w konsekwencji pełną realizacją traktatowych swobód będących podstawą Rynku Wewnętrznego.

Podobny charakter miała sprawa, w której samochód ciężarowy użytkowany w oparciu o umowę leasingu przez polskie przedsiębiorstwo transportowe został zatrzymany na granicy czesko-austriackiej przez austriackie służby graniczne. Od kierowcy zatrzymanego samochodu zażądano okazania oryginału umowy leasingu pojazdu. Pomimo przesłania faksem żądanego dokumentu, nałożono wysoką opłatę z tytułu nieokazania umowy w momencie kontroli. Według wyjaśnień austriackich służb kontrolnych opłata stanowiła kaucję na poczet postępowania wyjaśniającego i ewentualnej kary. Takie postępowanie nie zostało wszczęte do czasu interwencji Centrum SOLVIT.

Działanie władz austriackich pozostawało w sprzeczności ze wspomnianym wcześniej rozporządzeniem EWG Rady nr 881/92, zgodnie z którym zarobkowy transport drogowy rzeczy wewnątrz Wspólnoty wymaga licencji wspólnotowej ${ }^{3}$. Na podstawie art. 5 ust. 2 tego rozporządzenia Państwa Członkowskie wydają posiadaczowi licencji jej oryginał, który przechowywany jest przez przedsiębiorstwo transportu rzeczy oraz określoną liczbę poświadczonych za zgodność z oryginałem kopii, odpowiednio do liczby pojazdów, którymi dysponuje posiadacz licencji (jako właściciel czy np. w oparciu o umowę leasingu). W związku z powyższym wypis z licencji jest właściwym i wystarczającym dokumentem dla służb kontrolnych państw Wspólnoty dla stwierdzenia, czy dane przedsiębiorstwo transportowe oraz pojazd zostały dopuszczone przez właściwe władze w swym kraju do wykonywania towarowego transportu drogowego. Art. 5 ust. 4 rozporządzenia 881/92 wskazuje wyłącznie na poświadczoną za zgodność z oryginałem kopię licencji wspólnotowej jako dokument, który musi być okazywany na każde żądanie upoważnionego funkcjonariusza służb kontrolnych.

W wyniku interwencji SOLVIT oficjalne procedury administracyjne zmierzające do rozpatrzenia sprawy zostały wszczęte. Dzięki wyjaśnieniom przedstawionym przez polskie Centrum Koordynacyjne SOLVIT, władze austriackie przyznały, że działanie austriackich służb kontrolnych pozostawało w sprzeczności z rozporządzeniem 881/92 i zapłacona na poczet ewentualnej kary kaucja została zwrócona polskiemu przedsiębiorcy.

Wskazany powyżej przykład nieuzasadnionego ograniczenia w swobodnym świadczeniu usług transportowych przez polskich przedsiębiorców, dzięki interwencji SOLVIT został wyjaśniony. Kolejna administracyjna bariera w dostępie do unijnego rynku usług dla polskich usługodawców została wyeliminowana.

Dużo trudniej przedstawia się sytuacja polskich przedsiębiorców oferujących swoje usługi w Holandii. W tym wypadku bowiem nie tyle praktyka administracyjna, co krajowe uregulowania prawne, nakładają na usługodawców z nowych Państw Członkowskich dodatkowe wymagania kwestionowane przez nich jako pozostające w sprzeczności ze wspólnotową zasadą swobodnego świadczenia usług.

Polscy przedsiębiorcy pragną bowiem skorzystać z możliwości, jakie oferuje artykuł 49 Traktatu o ustanowieniu Wspólnot Europejskich (TWE) i świadczyć usługi w Królestwie Niderlandów. Ponieważ Traktat Akcesyjny ${ }^{4}$, zawierający uregulowania odnośnie przystąpienia m.in. Polski do Unii Europejskiej, nie przewiduje żadnych okresów przejściowych w stosunkach pomiędzy Polską i Niderlandami w zakresie świadczenia usług, artykuł 49 TWE oraz dyrektywa 96/71 dotycząca delegowania pracowników w ramach świadczenia usług znajdują pełne zastosowanie od dnia 1 maja 2004r. Jednakże władze holenderskie

\footnotetext{
${ }^{3}$ Art. 3 Rozporządzenia Rady EWG 881/92

${ }^{4}$ Traktat dotyczący przystąpienia Republiki Czeskiej, Republiki Estońskiej, Republiki Cypryjskiej, Republiki Łotewskiej, Republiki Litewskiej, Republiki Węgierskiej, Republiki Malty, Rzeczypospolitej Polskiej, Republiki Słowenii i Republiki Słowackiej do Unii Europejskiej z dnia 4 kwietnia 2003 r. ;Dz. U. UE L.03.236.17.
} 
stawiają wymogi uzyskania pozwolenia na pracę dla pracowników delegowanych przez polskiego usługodawcę. Takie dodatkowe wymagania stanowią ograniczenie swobodnego przepływu usług, co zostało potwierdzone przez ugruntowane orzecznictwo Europejskiego Trybunału Sprawiedliwości (ETS). Podobną kwestię rozpatrywał ETS w orzeczeniu Societé Rush Portuguesa $L D A^{5}$, w którym przedmiotem rozstrzygnięcia Trybunału były ograniczenia nakładane przez Francję na usługodawców portugalskich w chwilę po przystąpieniu Portugalii do Wspólnot Europejskich. ETS wskazał m.in. że uregulowania Traktatu nie pozwalają Państwu Członkowskiemu na wprowadzanie zakazów w stosunku do podmiotu świadczącego usługi, utworzonego w innym Państwie Członkowskim, w zakresie swobodnego przenoszenia się na terytorium przyjmującego Państwa Członkowskiego wraz ze wszystkimi pracownikami oraz „nie pozwalają Państwu Członkowskimu na wprowadzenie ograniczeń przepływu wyżej wspomnianych pracowników, np. poprzez (...) wymóg uzyskania pozwolenia na pracę". Trybunał podkreślił, że tego typu działania przyjmującego Państwa Członkowskiego powodują dyskryminację tego podmiotu w stosunku do podmiotów konkurencyjnych utworzonych w Państwie przyjmującym.

Mimo tak jasnego stanowiska Europejskiego Trybunału Sprawiedliwości, władze holenderskie podtrzymują swoje uregulowania, co w znacznym stopniu zakłóca funkcjonowanie rynku świadczenia usług i narusza postanowienia Traktatu. Interwencja SOLVIT ma w tym przypadku charakter wspomagajacy oficjalne działania władz polskich, majace na celu doprowadzenie do zniesienia wspomnianych wyżej ograniczeń i dyskryminacyjnego traktowania polskich usługodawców. Skargi, jakie wpływają do Centrum Koordynacyjnego SOLVIT od przedsiębiorców, stanowią dowód, że problem nie jest tylko akademickim sporem na temat kształtu Rynku Wewnętrznego i tworzących go swobód. Sprawy wprowadzone do systemu SOLVIT odnośnie ograniczeń w świadczeniu usług w Holandii stanowią konkretne przykłady skutków, jakie ograniczenia te wywierają na funkcjonowanie polskich przedsiębiorców na unijnym rynku usług.

Polskie Centrum SOLVIT koordynuje również rozwiązywanie podobnych problemów, ale wynikających z niewłaściwego stosowania prawa europejskiego przez polską administrację, zgłoszonych do systemu przez obywateli i przedsiębiorców z innych Państw Członkowskich. W tym przypadku, poprzez bezpośredni kontakt z organem polskiej administracji lub za pośrednictwem punktów kontaktowych systemu SOLVIT znajdujących się w ministerstwach i urzędach centralnych, Centrum SOLVIT, podejmuje działania zmierzające do skorygowania błędu polskiego urzędu.

Przykładem sprawy, w której działania polskiego Centrum Koordynacyjnego miały na celu skorygowanie polskiej praktyki administracyjnej, była skarga przedstawiona do systemu SOLVIT przez szwedzkie przedsiębiorstwo odnośnie uciążliwości procedur administracyjnych przewidzianych przez polskie ustawodawstwo. Sprawa dotyczyła dokumentacji, jaką zobowiązany jest przedstawić przedsiębiorca dokonujący wewnątrzwspólnotowej dostawy towarów dla celów zastosowania stawki $0 \%$ VAT, a wynikających z polskiej ustawy o podatku od towarów i usług ${ }^{6}$. Przedsiębiorca zwracał uwagę m.in. na szczególną uciążliwość wynikającą z konieczności potwierdzania dostawy na dokumentach transportowych, jak również wymogu wystawiania pisemnych oświadczeń o przyjęciu towaru przez unijnego odbiorcę. Kształt ani treść takiego dokumentu nie jest określona w przepisach o VAT. Ponadto przedsiębiorca wskazał, że urzędy skarbowe interpretują wyrażenie „dokument" w sposób dosłowny, czyli oczekują przedstawienia oświadczenia odbiorcy w formie papierowej. Natomiast wiele firm nie dysponuje takimi dokumentami ponieważ przepływ towarów rejestrowany jest $\mathrm{w}$ dostępnej dla kontrahentów informatycznej bazie danych. Takie procedury uznawane są przez przedsiębiorców z innych Państw Członkowskich za nieuza-

\footnotetext{
5 Orzeczenie ETS z dnia 27 marca 1990r, Rush Portugesa LDA przeciwko Office national d'immigration, C-113/89.

${ }^{6}$ Art. 42 ust. 3 ustawy o podatku od towarów i usług z dnia 11 marca 2004 r. (Dz. U. nr 54, poz. 535).
} 
sadnione obciążenie oraz barierę w prowadzonej przez nich działalności handlowej.

Centrum SOLVIT podjęło się interwencji w powyższej sprawie. Pomimo iż uregulowania polskiej ustawy nie pozostają $\mathrm{w}$ sprzeczności z prawem europejskim, zgodnie $\mathrm{z}$ ustalonym orzecznictwem ETS nie tylko niezgodność przepisów krajowych z prawem UE, ale również uciążliwość procedur przewidzianych przez uregulowania wewnętrzne Państwa Członkowskiego, może być przedmiotem skargi skierowanej do Trybunału i może zostać uznana za nieuzasadnione ograniczenie swobód gwarantowanych przez Traktat. Centrum SOLVIT zwróciło się więc do kompetentnych w tym zakresie organów administracji polskiej zwracając uwagę na konieczność przeanalizowania opisanych wyżej procedur i rozważenie dokonania ewentualnych zmian, których celem byłoby ich uproszczenie i, w konsekwencji, ułatwienie dokonywania wewnątrzwspólnotowej wymiany towarów zgodnie z traktatową zasadą swobodnego przepływu towarów.

SOLVIT jest systemem, który utworzony został po to, aby wspierać obywateli i przedsiębiorców w zapewnieniu sobie respektowania praw przysługujących im $\mathrm{w}$ oparciu o uregulowania prawa europejskiego. W niektórych przypadkach do wyegzekwowania tych praw konieczny jest proces sądowy: ustala on wykładnię prawa, ustanawia ważne precedensy i służy jako środek powstrzymujący przed popełnieniem wykroczenia w przyszłości. Ale rozstrzyganie sporów może trwać latami, a to zwykle zbyt długo, w szczególności dla przedsiębiorcy, któremu czasowe choćby ograniczenia w prowadzeniu działalności mogą przynieść nieodwracalne straty. Gdy problemy wynikają z błędnego stosowania prawa, szczególne cenna jest możliwość szybkiego zadośćuczynienia i to bez wnoszenia sprawy do sądu. Taką alternatywą dla długiego i często kosztownego postępowania sądowego jest właśnie system SOLVIT. W szczególności dla polskich przedsiębiorców wchodzących dopiero na unijny rynek i stojących przed nowymi dla nich wyzwaniami, SOLVIT jest cennym instrumentem wspierającym ich w funkcjonowaniu na Rynku Wewnętrznym.

Należy jednak pamiętać, że SOLVIT jest alternatywną dla postępowania sądowego drogą nieformalnego rozwiązywania sporów. W związku z tym przedstawienie sprawy do systemu SOLVIT nie powoduje wstrzymania biegu terminów, których, w oparciu o ustawodawstwo krajowe, należy przestrzegać dla zagwarantowania możliwości skorzystania z pewnych praw (np. odwołania się do właściwego nadrzędnego organu administracji). Z nieformalnego charakteru tej drogi rozwiązywania problemów wynika również fakt, że zaproponowane przez SOLVIT rozwiązanie nie jest więc wiążące dla wnioskodawcy. W przypadku gdy nie znaleziono rozwiązania lub gdy zaproponowane rozwiązanie nie satysfakcjonuje wnioskodawcy, nie ma on możliwości jego formalnego zakwestionowania w ramach SOLVIT. Może nadal dochodzić swoich praw na drodze sądowej. System SOLVIT działa bezpłatnie.

Sprawy mogą być zgłaszane do SOLVIT bezpośrednio przez obywateli lub przedsiębiorców lub za pośrednictwem zrzeszających ich organizacji. Organizacje takie mają możliwość czynnego włączenia się $\mathrm{w}$ działanie systemu poprzez zarejestrowanie się w nim jako jednostka stowarzyszona.

Należy jednak pamiętać o podstawowych zasadach, jakie rządzą rozwiązywaniem problemów w ramach systemu SOLVIT:

- SOLVIT zajmuje się wyłącznie sprawami, które mają charakter „transgraniczny” czyli nie dotyczą sytuacji czysto wewnętrznej; SOLVIT nie może interweniować, gdy problem wynikł $\mathrm{z}$ niewłaściwego stosowania prawa europejskiego wobec obywatela lub przedsiębiorcy polskiego przez organ administracji krajowej;

- tą drogą mogą być rozwiązywane tylko te sprawy, które dotyczą problemu wynikającego z niewłaściwego stosowania prawa przez organ administracji publicznej; SOLVIT nie zajmuje się problemami, które pojawiły się w relacjach : przedsiębiorca - przedsiębiorca, konsument - przedsiębiorca;

- SOLVIT nie może również interweniować w sytuacji, gdy postępowanie sądowe w danej sprawie zostało już wszczęte. 